\title{
PENGEMBANGAN BAHAN AJAR FISIKA BERBASIS SCIENTIFIC APPROACH
}

\author{
Wulan Muji Lestari ${ }^{1}$, Tri Ariani, ${ }^{2}$ Ovilia Putri Utami Gumay ${ }^{3}$ \\ Program Studi Pendidikan Fisika STKIP PGRI LUBUKLINGGAU ${ }^{1,2,3}$ \\ wulan.muji11@gmail.com ${ }^{1}$
}

Submit, 16-11-2018 Accepted, 26-12-2018 Publish,27-12-2018

\begin{abstract}
: the aim of the study was to develop physic teaching book with scientific approach based on light waves material for the eleventh grade students at SMA Negeri 5 Lubuklinggau. It was a research and development study. The subject in the study was all of the eleventh grade students of science class and the subject was the large group of students at XI IPA 2 at SMA Negeri 5 Lubuklinggau consist of 34 students which was collected through simple random sampling. The data collection was executed from interview, questionnaire, and test. By the validation, it was found that the result was in 'good' category with percentage 76,58\%. Students response on the teaching book with scientific approach based was $83,35 \%$. Furthermore, by the daily examination results, $82 \%$ students got the average scores above 70 out of 10 questions. The score of ttable with degree of freedom $n-1=34-1=33$ and $\alpha=0,05$ tobtained $=6,53$ and ttable = 1,692 because tobtained $\geq$ ttable so that Ha was accepted. In conclusion, the teaching book with scientific approach based which was developed has been valid, practical and effective.
\end{abstract}

Keywords: Teaching Book, Scientific Approach, Reseach and Development

\begin{abstract}
Abstrak: tujuan penelitian, mengembangkan buku ajar fisika berbasis scientific approach pada materi gelombang cahaya siswa Kelas XI SMA Negeri 5 Lubuklinggau. Metode penelitian ini adalah research and development. Subjek dalam penelitian ini adalah seluruh kelas XI IPA dan subjek penelitian kelompok luas dalam penelitian ini adalah kelas XI IPA 2 SMA Negeri 5 Lubuklinggau yang terdiri dari 34 siswa yang diambil dengan teknik simple random sampling. Pengumpulan data dilakukan dengan teknik wawancara, angket, dan tes. Validasi yang dilakukan mendapatkan hasil dengan kategori baik yaitu dengan presentase 76,58\%. Respon siswa terhadap buku ajar berbasis scientific approach yaitu 83,35\%. Selain itu dari hasil tes ulangan harian $82 \%$ siswa yang memperoleh nilai di atas 70 dari 10 butir soal tes. Nilai $t_{\text {tabel }}$ dengan derajat kebebasan $(d k)=n-1=34-1=33$ dan $\alpha=0,05 t_{\text {hitung }}=6,53$ dan $t_{\text {tabel }}=1,692$ karena $t_{\text {hitung }} \geq$ $t_{\text {tabel }}$ maka $H_{a}$ diterima. Simpulan, buku ajar scientific approach yang dikembangkan telah valid, praktis, dan efektif.
\end{abstract}

Kata Kunci : Buku Ajar, Scientific Approach, Reseach and Development.

\section{PENDAHULUAN}

Negara indonesia saat ini berkembang sangat baik dan pesat. Banyak cara untuk memajukan bangsa indonesia dari berbagnai sektor. Salah satunya dari sektor pendidikan. Pendidikan merupakan hal yang sangat penting karena dengan adanya pendidikan akan menghasilkan output atau tenagatenaga yang berkualitas dan dapat memajukan bangsa indonesia. Oleh karena itu pemerintah Indonesia selalu berupaya meningkatkan mutu pendidikan di Indonesia.

Berdasarkan studi pendahuluan yang telah dilakukan pada tanggal 20-21 Juli 2018 menggunakan teknik wawancara dengan guru Fisika dan siswa kelas XI IPA SMA Negeri 5 Lubuklinggau didapatkan hasil bahwa SMA Negeri 5 Lubuklinggau menggunakan kurikulum 2013 revisi 2017. Dengan menggunakan kurikulum terbaru sebagian besar siswa masih mengalami kesulitan dalam menjalankan 
kurikulum 2013. Dalam kurikulum 2013 menggunakan pendekatan scientific dalam proses KBM. Sebagian besar siswa di kelas kesulitan saat menerapkan pendekatan scientific kedalam proses KBM diantaranya materi yang belum dipahami oleh siswa ialah gelombang cahaya, inilah yang menyebabkan rendahnya pemahaman siswa terhadap konsep dan praktikum yang ada dalam materi, hal tersebut membuat siswa mengikuti proses belajar belum optimal.

Siswa juga menuturkan bahwa mereka lebih suka belajar dengan menggunakan metode praktikum dibandingkan belajar di dalam kelas. Banyak faktor yang mempengaruhi hal tersebut misalnya cara penyampaian materi oleh guru yang monoton, tidak menarik, pembelajaran hanya mengandalkan buku paket atau dari penerbit sebagai sumber belajar, kurangya lembar kerja siswa, serta kurangnya peralatan praktikum. Siswa mengharapkan sebuah buku ajar yang memiliki tampilan menarik dan tidak membosankan serta terdapat motivasi belajar Fisika.

Berdasarkan hasil wawancara didapatkan pula bahwa buku ajar yang digunakan masih kurang. Buku ajar yang digunakan masih mengandalkan buku paket atau buku dari penerbit. Di dalam buku paket tersebut kurang mendukung dengan model pembelajaran yang digunakan untuk kurikulum 2013 sekarang. Dalam buku paket tersebut LKP yang disediakan belum lengkap karena hanya terdapat satu LKP. Sedangkan dalam kurikulum 2013 siswa dituntut agar lebih aktif dengan menggunakan pendekatan scientific.

Berdasarkan latar belakang permasalahan yang telah dikemukakan di atas, penulis tertarik untuk melakukan penelitian dengan judul "Pengembangan Bahan ajar Fisika Berbasis Scientific Approach Pada Materi Gelombang Cahaya Siswa Kelas XI SMA Negeri 5 Lubuklinggau Tahun Ajaran 2018/2019”.
Tujuan dari dilakukannya penelitian ini adalah: 1) Untuk mengetahui cara mendesain dan mengembangkan baha ajar Fisika berbasis scientific approach pada materi Gelombang Cahaya siswa Kelas XI SMA Negeri Lubuklinggau Tahun Pelajaran 2018/2019., 2) Untuk mengetahui bahan ajar Fisika berbasis scientific approach pada materi Gelombang Cahaya Siswa Kelas XI SMA Negeri 5 Lubuklinggau Tahun Pelajaran 2018/2019 apakah sudah valid, praktis, dan efektif.

\section{LANDASAN TEORI \\ Buku Ajar}

Prastowo (2014) mendefinisikan bahan ajar adalah seperangkat materi yang disusun secara sistematis, baik tertulis maupun tidak, sehingga tercipta lingkungan atau susasana yang memungkinkan peserta didik untuk belajar. Sukerni (2014) menjelaskan buku ajar dapat menuntut pembelajaran agar aktif dalam pembelajaran melalui pemberian materi yang disertai dengan gambar yang sangat berkaitan dengan kehidupan siswa, tugas mandiri yang dapat dikerjakan secara individu atau kelompok setiap materi, ringkasan materi setiap bab dan tes akhir bab.

Jadi dapat disimpulkan bahwa buku ajar adalah buku yang dipakai untuk mempelajari atau mendalami suatu subjek pengetahuan dan ilmu serta teknologi yang dapat menuntut pembelajaran agar aktif dalam pembelajara yang disusun berdasarkan standar nasional pendidikan.

Dalam penelitian ini buku ajar yang dikembangkan berbasis scientific approach. artinya buku ajar yang dikembangkan menggunakan tahap-tahap dari scientific approach atau pendekatan saintifik untuk struktur dalam buku ajar. Buku ajar cetak memiliki kelebihan yaitu praktis dibawa kemana-mana, ringan, dan cepat mudah diakses. Namun buku ajar tetap memiliki kekurangan yaitu tidak 
mampu mempresentasikan gerak dan sulit memberikan bimbingan.

\section{Scientific Approach}

Pendekatan pembelajaran saintifik adalah pembelajaran yang merujuk pada teknik-teknik investigasi atas fenomena atau gejala memperoleh pengetahuan baru atau mengoreksi, dan memadukan pengetahuan sebelumnya. Pendekatan pembelajaran dapat disebut ilmiah (saintifik), metode pencarian (method of inquiry) harus berbasis pada bukti-bukti dari objek yang dapat diobservasi, empiris, dan terukur dengan prinsip-prinsip penalaran yang spesifik.

Karena itu, metode ilmiah (saintifik) umumnya memuat serial aktivitas pengoleksian data melalui observasi dan ekperimen, kemudian memformulasi dan menguji hipotesis (Susilo,dkk, 2016). Dalam definisi lain Pendekatan saintifik (scientific approach) merupakan salah satu pendekatan pembelajaran yang berorientasi atau berpusat pada siswa (Yerimadesi, 2016).

Berdasarkan pendapat beberapa ahli di atas dapat disimpulkan bahwa pendekatan scientific adalah pendekatan yang merujuk pada teknik-teknik investigasi atas fenomena atau gejala untuk mendapatkan pengetahuan baru dan pembelajaran yang berorientasi pada siswa. Pendekatan saintifik (scientific approach) memiliki 5 tahapan di dalamnya. Tahapan tersebut yaitu : Mengamati, menanya, menalar, mencoba, mengkomunikasikan.

\section{METODE PENELITIAN}

Dalam penelitian ini untuk mengembangkan sebuah bahan ajar berbasis scientific approach pada materi gelombang cahaya menggunakan model pengembangan Sugiyono. Dimana dalam penelitian ini mengadaptasi 9 langkah dari 10 langkah milik Sugiyono. Adapun langkah dari pengembangan model Sugiyono terdapat 10 tahapan yaitu: tahap potensi dan masalah, pengumpulan data, desain produk, validasi desain, revisi desain, uji coba produk, revisi produk, uji coba pemakaian, revisi produk dan produksi massal, namun peneliti hanya menggunakan 9. Teknik pengumpulan data dalam penelitian ini menggunakan angket, wawancara dan tes. Adapun instrumen yang digunakan untuk melihat kelayakan dan keefektifan buku ajar yang dikembangkan yaitu menggunakan, angket kevalidan, angket kepraktisan, wawancara dan soal tes.

Buku ajar dikembangkan menggunakan ms word, photoshop, dan photoscape. Buku ajar draf final ini adalah buku ajar yang akan digunakan dalam penelitian di SMA Negeri 5 Lubuklinggau Dimana hasil dari desain yang dilakukan oleh peneliti harus melalui tahap FGD yang dilakukan oleh Ibu Welly Widya Lestari, S.Pd dan Bapak Ahmad Amin, M.Si. FGD dilakukan guna untuk bisa saling bertukar pikiran antara peneliti dengan tim FGD agar produk yang dikembangkan semakin baik sebelum produk tersebut akan divalidasi oleh para validator yang ahli di bidangnya masing-masing.

Validator yang akan memvalidasi buku ajar yang dikembangkan adalah ahli materi oleh bapak Yaspin Yolanda, M.Pd.Si dan ibu R.Okti Syahli, S.Pd ahli tata bahasa dilakukan oleh ibu Dr. Yohanna Satinem, M.Pd serta ahli media dilakukan oleh bapak Dodik Mulyono, M.Pd.

Peneliti menggunakan desain One Shot Case Study dimana peneliti hanya melihat hasil akhir dari sebuah penelitian. Peneliti melakukan 3 tahap pengujian yaitu dengan menggunakan One To One, uji kelompok terbatas dan uji kelompok luas. Pada uji One To One peneliti menggunakan lembar wawancara dengan 3 orang siswa kelas XI MIPA 1, kemudian memberikan angket dengan 6 orang siswa kelas XI MIPA 3. Angket ini berisi 10 pernyataan yang harus diberikan tanggapan oleh siswa dan guru. Pada akhirnya tahap uji coba kelompok luas 
dilakukan di kelas XI MIPA 2 SMAN 5 Lubuklinggau dengan menggunakan 10 soal tes sebagai instrumen pengujian keefektifan produk. Untuk menghitung skor angket menggunakan rumus:

$$
\text { Persentase }=\frac{\text { skor yang diperoleh }}{\text { skor maksimum }} \times 100 \%
$$

Persentase ketuntasan menurut Fatmawati (2016) ada 2 yaitu ketuntasan individual dan ketuntasan klasikal. Persentase ketuntasan individual

$$
\mathrm{N}=\frac{\text { nilai yang didapat }}{\text { nilai maksimum }} \times 100 \%
$$

Persentase ketuntasan klasikal

$$
\mathrm{N}=\frac{\text { siswa yang tuntas }}{\text { jumlah seluruh siswa }} \times 100 \%
$$

Untuk menguji hipotesis tersebut dapat menggunakan t-test satu sampel dengan rumus sebagai berikut:

$$
\mathrm{t}=\frac{\overline{\mathrm{x}}-\mu_{0}}{\frac{\mathrm{s}}{\sqrt{\mathrm{n}}}}
$$

\section{HASIL DAN PEMBAHASAN}

Pada penelitian ini dipilih 1 pokok bahasan materi, materi yang dipilih untuk pengembangan buku ajar berbasis pendekatan saintifik ini adalah materi gelombang cahaya. Pembelajaran akan dilaksanakan dua kali dalam 1 minggu. Dalam satu pertemuan dengan waktu $2 \mathrm{x}$ 45 menit dalam satu hari maka sebisa mungkin guru memanfaatkan waktu yang diberikan agar bisa mencapai keterlaksanaan pembelajaran yang maksimal. Peneliti mengambil 1 materi saja karena mengingat adanya keterbatasan waktu dan biaya penelitian. Serta dimaksudkan untuk membantu mempermudah siswa dalam memahami materi yang diajarkan.

Buku ajar yang akan dikembangkan akan didesain dengan menggunakan program photoshop, photoschape, dan $\mathrm{ms}$ word. Buku ajar yang dikembangkan didesain semenarik mungkin dengan tampilan yang menarik dan perpaduan warna yang dapat menarik perhatian siswa untuk belajar. Selain itu dalam buku ajar nantinya akan mengunakan beberapa tambahan gambar kartun dan gambar yang sesuai dengan materi yang digunakan. Gambar digunakan untuk membuat siswa lebih paham dengan materi dan membuat siswa tidak jenuh dan bosan dalam membaca buku.

Buku ajar ini dibuat dengan 2 macam yaitu buku ajar bagi guru dan buku ajar bagi siswa. Buku guru didalamnya memuat materi, Lembar Kerja Praktikum (LKP), contoh soal dan pembahasannya, soal latihan dan pembahannya, serta soal evaluasi dan penyelesaiannya. Sedangkan pada buku siswa terdapat materi, Lembar Kerja Praktikum (LKP), contoh soal, dan soal latihan.

Buku ajar yang dikembangkan melewati beberapa tahapan untuk mendapatkan buku ajar final atau buku ajar yang digunakan untuk penelitian. Tahapan tersebut seperti yang dijelaskan di bawah ini:

\section{Buku ajar Draf I}

Pada buku ajar draf 1, peneliti telah merancang buku ajar berbasis scientific approach dengan materi gelombang cahaya yang belum divalidasi dan belum dinilai. Buku ajar yang dikembangkan adalah yang paling awal dan sangat sederhana. Buku ajar dikembangkan menggunakan ms word, photoshop, dan photoscape. Buka ajar dikembangkan terdiri dari dua buku yaitu: buku siswa dan buku guru. Berikut buku ajar draf 1 pada gambar 2 . 


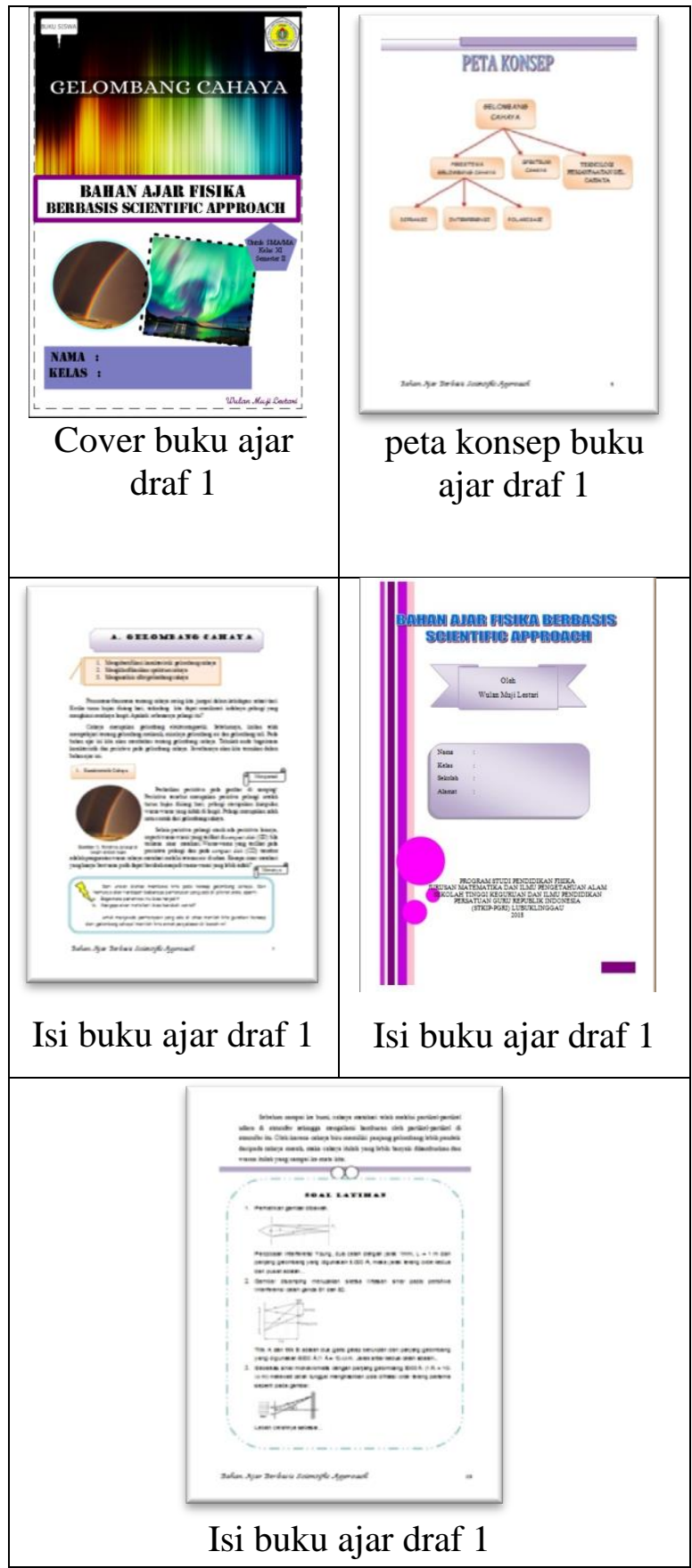

Gambar 1 Draf buku ajar I

Setelah buku ajar draf 1 selesai dirancang, selanjutnya peneliti melakukan Forum Grup Diskusi (FGD) bersama guru Fisika di MA Negeri 1 Model Lubuklinggau dan dosen Fisika untuk memberikan saran dan masukan terhadap buku ajar yang dirancang.

\section{Buku ajar draf II}

Pada buku ajar draf II ini merupakan perbaikan dari buku ajar draf I sebelumnya. buku ajar direvisi dari saran dan masukan melalui Forum Grup Diskusi (FGD) yang diberikan pada buku ajar draf 1 tadi, selanjutnya penulis melakukan beberapa hal yang harus diperbaiki sebelum melakukan penelitian. Buku ajar dikembangkan menggunakan ms word, photoshop, dan photoscape. Berikut perbaikan setelah melakukan Forum Grup Diskusi (FGD) sesuai saran, masukan dan kritik yang disajikan pada gambar 3 buku ajar draf II.

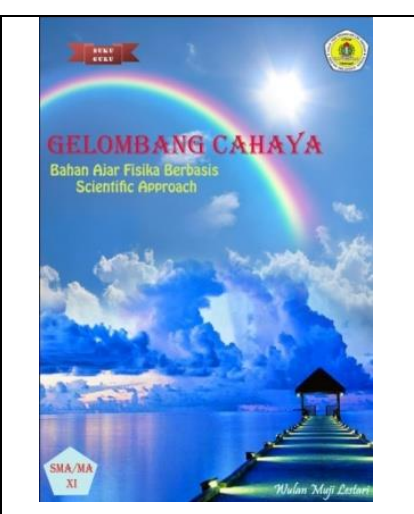

Cover buku ajar drafII

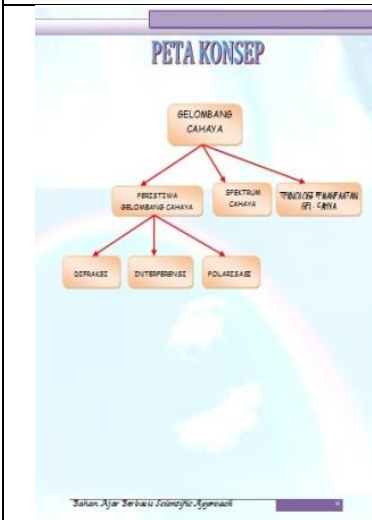

Isi buku ajar draf II

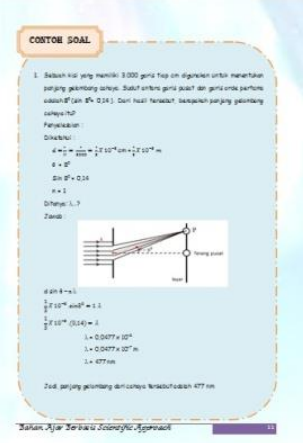

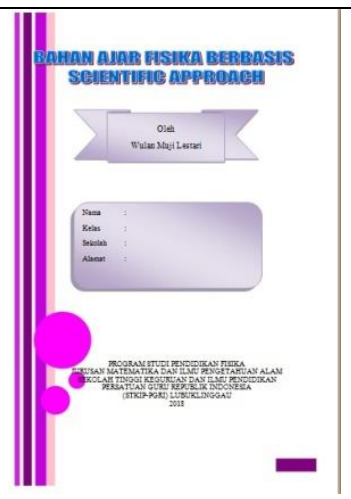

Isi buku ajar draf II

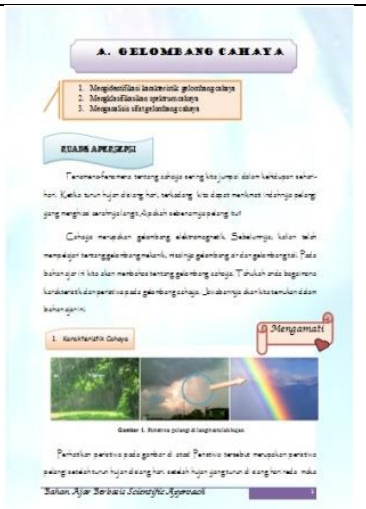

Isi buku ajar draf II

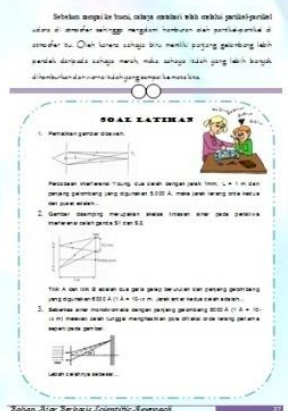

Isi buku ajar draf II 


\begin{tabular}{l}
\hline Isi buku ajar draf II \\
Gambar 2 Draf buku ajar II
\end{tabular}

Dari buku ajar draf 1 dan draf 2 yang telah dinilai dan diperbaiki oleh validator ahli, dosen Fisika, dan guru Fisika akhirnya didapat buku ajar final yang dapat digunakan dalam penelitian. Buku ajar dikembangkan menggunakan ms word, photoshop, dan photoscape. Buku ajar draf final ini adalah buku ajar yang akan digunakan dalam penelitian di SMA Negeri 5 Lubuklinggau. Berikut buku ajar final dapat dilihat pada gambar 4.

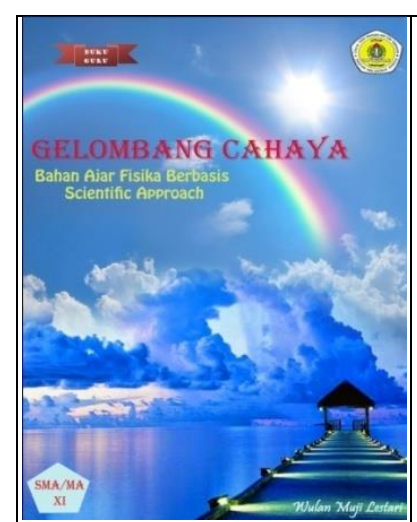

Cover buku ajar draf

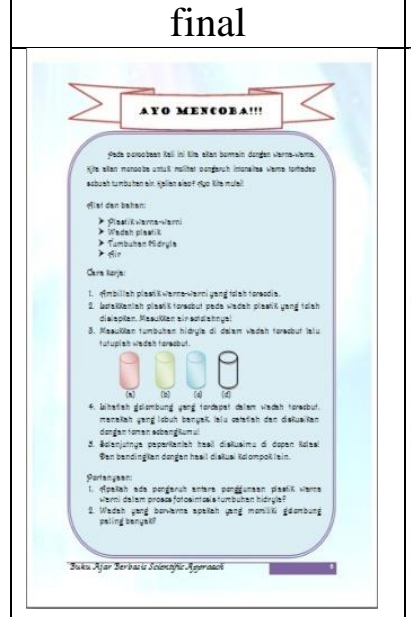

Isi buku ajar draf

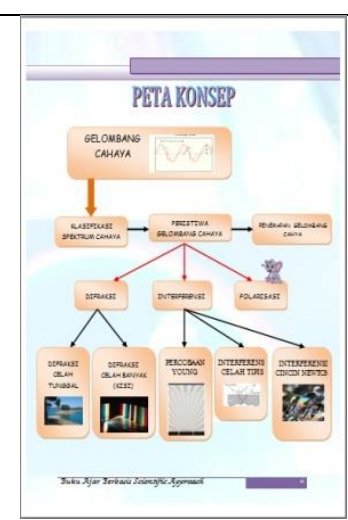

Isi buku ajar draf final

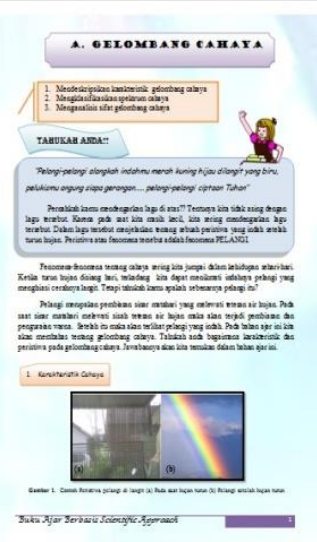

Isi buku ajar draf

\section{Gambar 3 Draf buku ajar Final}

Setelah melewati beberapa kali revisi, pada buku ajar final ini penulis tetap memberikan buku ajar kepada para ahli untuk dinilai. Pada buku ajar final, ahli materi dan media memberikan nilai yang sangat baik dan tanpa ada yang harus diperbaiki. Sedangkan untuk ahli bahasa juga memberikan nilai yang sangat baik, tetapi hanya ada satu kata pengetikan yang kurang tepat. Untuk ahli bahasa menyarankan tidak perlu melakukan perbaikan yang banyak hanya merevisi pengetikan kata yang salah.

\section{Kelayakan Buku Ajar}

Kelayakan dari buku ajar Fisika berbasis scientific approach ini dilihat dari hasil validasi yang dilakukan kepada beberapa ahli dan dari beberapa aspek. Evaluasi ahli dilakukan untuk menyempurnakan buku ajar yang dikembangkan dari segi materi, media, dan bahasa. Sebagai ahli materi dipilih seorang dosen prodi Fisika yaitu bapak Yaspin Yolanda, M.Pd.Si dan sebagai tambahan guru Fisika sekolah ibu R. Okti Syahli, S.Pd.

Sebagai ahli media dipilih dosen prodi Fisika yaitu bapak Dodik Mulyono, M.Pd. Sedangkan sebagai ahli bahasa dipilih seorang dosen prodi bahasa Indonesia yaitu ibu Dr. Yohana Satinem, M.Pd. Ketiga validator ini dipilih melalui rekomendasi dari pihak LP4MK STKIPPGRI Lubuklinggau untuk memberikan penilaian dan saran terhadap buku ajar yang peneliti kembangkan. Sedangkan guru sekolah dipilih oleh peneliti. 
Instrumen yang digunakan adalah angket terbuka, berdasarkan indikator dan saran yang dibutuhkan dalam mengembangkan buku ajar berbasis scientific. Secara rinci peneliti uraikan sebagai berikut.

Validasi materi dilakukan kepada dua validator ahli materi yaitu kepada dosen Fisika STKIP PGRI Lubuklinggau dan guru Fisika SMA Negeri 5 Lubuklinggau. Validasi materi yang dilakukan kepada dosen Fisika yaitu bapak Yaspin Yolanda, M.Pd.Si sebanyak tiga kali. Hal ini dimaksudkan untuk memaksimalkan dan agar materi dalam buku ajar yang dikembangkan semakin baik. Dari hasil analisis validasi yang ketiga ini termasuk dalam kategori sangat baik yaitu dengan persentase $87,50 \%$. Artinya buku ajar yang dikembangkan memiliki progres peningkatan yang baik dari setiap validasinnya.

Sedangkan validasi yang dilakukan guru Fisika yaitu ibu R. Okti Syahli, S.Pd hanya dilakukan sekali. Hal ini dikarenakan sebelumnya buku ajar telah divalidasi oleh ahli yang lainnya yaitu Bapak Yaspin Yolanda, M.Pd,Si. Hasil tanggapan dari validasi komponen materi mendapatkan skor 39. Dari hasil analisis validasi ini termasuk dalam kategori sangat baik yaitu dengan persentase $81,25 \%$. Ibu Okti memberikan beberapa saran untuk perbaikan buku ajar yaitu perdalam lagi materi pada tahap-tahap saintifik dan kedalaman materi harus sesuai dengan kemampuan siswa.

Sehingga hasil akumulasi dari validasi komponen materi yang telah dilakukan kepada dua ahli materi terhadap buku ajar yang dikembangkan dapat diakumulasikan menjadi $75 \%$ yang termasuk kedalam kategori baik. Sehingga dengan perolehan persentase yang dalam kategori baik maka buku ajar yang dikembangkan layak digunakan dari segi materi.

Validasi Kedua adalah hasil dari validasi tata bahasa. Validasi tata bahasa dilakukan kepada ahli bahasa yaitu dosen bahasa indonesia, ibu Dr. Yohana
Satinem, M.Pd. Validasi yang dilakukan dari segi tata bahasa ini hanya dilaksanakan satu kali. Hasil tanggapan dari validasi komponen tata bahasa mendapatkan skor 19. Dari hasil analisis validasi ini termasuk dalam kategori baik yaitu dengan persentase $79,1 \%$ dan buku ajar yang dikembangkan layak digunakan dari tata bahasa dengan tetap adanya beberapa revisi sesuai dengan saran. Ibu Dr. Yohana Satinem, M.Pd memberikan beberapa saran untuk perbaikan buku ajar yaitu perbaiki kata pengantar karena terdapat kekurangan kalimat dan perbaiki penulisan serta perhatikan penggunaan kata depan dan awalan.

Validasi ketiga adalah hasil dari validasi media atau desain. Validasi media atau desain dilakukan kepada ahli media desain yang ada di STKIP PGRI Lubuklinggau yaitu salah satu dosen matematika yang menjadi ahli media di STKIP PGRI Lubuklinggau yaitu bapak Dodik Mulyono, M.Pd. Hasil tanggapan dari validasi komponen tata bahasa mendapatkan skor 30. Dari hasil analisis validasi ini termasuk dalam kategori sangat baik yaitu dengan persentase $83,3 \%$ dan buku ajar yang dikembangkan layak digunakan dari segi media desain dengan tetap adanya beberapa revisi sesuai dengan saran.

Berdasarkan hasil penilaian tahap validasi oleh para ahli yang telah dilakukan terhadap buku ajar berbasis scientific approach yang telah diuraikan di atas menunjukkan maka kevalidan buku ajar yang dikembangkan persentasenya mencapai $79,1 \%$ yang termasuk dalam kategori baik sehingga buku ajar yang dikembangkan layak untuk digunakan dalam kegiatan belajar mengajar dengan tetap melakukan perbaikan sesuai dengan saran dan komentar yang diberikan dan buku ajar berbasis scientific approach dapat digunakan untuk tahap selanjutnya yaitu uji coba yang akan dilaksanakan di SMA Negeri 5 Lubuklinggau. Hasil validasi 
yang telah dilaksanakan oleh ketiga ahli dapat dilihat pada tabel 1 .

Tabel 1 Rekapitulasi Tanggapan Ketiga Ahli

\begin{tabular}{ccccc}
\hline No. & Validator & $\begin{array}{c}\text { Hasil } \\
\text { Penilaian }\end{array}$ & Presentase & Kategori \\
\hline 1 & $\begin{array}{l}\text { Validasi } \\
\text { Materi }\end{array}$ & 144 & $75 \%$ & Baik \\
\hline 2 & Validasi Media & 30 & $83,3 \%$ & $\begin{array}{c}\text { Sangat } \\
\text { baik }\end{array}$ \\
\hline 3 & $\begin{array}{l}\text { Validasi Tata } \\
\text { Bahasa }\end{array}$ & 19 & $79,1 \%$ & Baik \\
\hline \multicolumn{2}{c}{ Total } & 193 & $76,58 \%$ & Baik \\
\hline
\end{tabular}

\section{Kepraktisan Buku Ajar}

Kepraktisan buku ajar di ujikan dengan melewati beberapa uji coba. Uji coba yang dilakukan adalah uji coba melalui tahapan uji coba one to one, kelompok kecil, dan kelompok luas untuk melihat kepraktisan buku ajar yang dilaksanakan di SMA Negeri 5 Lubuklinggau. Setiap uji coba dilakukan dengan mengunakan subjek penelitian yang berbeda.

Uji coba one to one dilaksanakan pada Senin, 23 Juli 2018, dengan melakukan wawancara kepada tiga orang siswa kelas XI MIA I. Uji coba one to one dilakukan di dalam kelas pada saat jam pelajaran Fisika. Hal ini dikarenakan guru Fisikanya yaitu ibu Siska, S.Pd telah memberikan izin untuk menggunakan kelasnya. Langkah-langkah yang dilakukan dalam uji coba one to one adalah: (a) siswa diminta untuk membaca atau melihat-lihat sekilas buku ajar berbasis scientific approach selama \pm 5 menit ; (b) siswa diminta untuk memperhatikan materi yang diambil secara acak sebagai sampel untuk ditanyakan; (c) setelah itu siswa ditanya secara lisan tentang materi yang ditanya, apabila jawaban siswa sama seperti apa yang kita pikirkan artinya keterbacaannya baik, produk yang dihasilkan praktis dan materi yang disajikan mudah dimengerti. (d) setelah itu siswa ditanya secara lisan atau wawancara dengan beberapa pertanyaan mengengai buku ajar berbasis scientific approach.
Hasil wawancara one to one pada buku ajar berbasis scientific approach; dilakukan pada tiga indikator yaitu: a) desain buku ajar; b) kemudahan pemahaman materi; dan c) keterbacaan isi materi; tersebut. Pelaksanaan uji coba one to one dilakukan guna melihat kepraktisan penggunaan buku ajar berbasis scientific approach.

Pelaksanaan uji coba one to one yang dilakukan oleh tiga siswa menyatakan bahwa buku ajar berbasis scientific approach sangat menarik dilihat dari segi penampilan, desain, dan matei yang digunakan. Materi yang disajikan mudah dipahami karena penyajiannya lengkap beserta gambar dan kesesuaian antara gambar dengan ilustrasi sangat tepat dan dapat membuat materi lebih mudah dimengerti. Pada tahap uji coba one to one buku ajar berbasis scientific approach didapatkan hasil dari pelaksanaan tahap uji coba one to one bahwa tidak ada masukan maupun perbaikan dari yang disarankan, itu artinya buku ajar tersebut dapat digunakan untuk tahap uji coba selanjutnya tanpa revisi, jawaban siswa diukur dengan cara analisis deskriptif kuantitatif dilihat dari jawaban yang diberikan pada saat wawancara berlangsung, dan dapat digunakan pada tahap selanjutnya yang akan diuji kepraktisanya dalam pelaksanaan uji coba kelompok kecil.

Uji coba kelompok kecil dilaksanakan pada hari selasa 24 juli 2018 di kelas XI IPA 3 dengan 6 orang siswa. Siswa yang dipilih merupakan rekomendasi dari guru Fisika yang mengajar di kelas tersebut. Pada saat uji coba kecil/terbatas pelaksanaannya di luar kelas. Hal ini dikarenakan agar tidak mengganggu jam pelajaran Fisika dan tidak mengganggu siswa lain untuk belajar. Pada saat uji coba kecil dilaksanakan yang dilakukan oleh peneliti untuk mendapatkan respon siswa menggunakan angket yaitu : 1) meminta siswa untuk melihat dan membaca sekilas 
buku ajar berbasis scientific approach sekitar \pm 20 menit, dan 2) memberikan tanggapan dan komentar tentang buku ajar yang dikembangkan melalui angket yang diberikan. 3) peneliti menajukan beberapa pertanyaan ringan mengenai buku ajar berbasis scientific approach yang telah dibaca sekilas. Uji coba kelompok terbatas juga digunakan untuk melihat tingkat kepraktisan dari buku ajar yang dikembangkan dengan menggunakan angket berjenis Check List dan terbuka.

Angket yang diberikan untuk penilaian buku ajar berbasis scientific approach indikatornya sama seperti lembar wawancara yaitu, 1) kemenarikan bahan pembelajaran Fisika, 2) keterbacaan materi, dan 3) kemudahan pemahaman materi. Dari angket respon siswa yang telah diberikan hanya 1 orang siswa yang memberikan komentarnya dan 5 orang siswa lainnya tidak memberikan komentar. Untuk siswa yang tidak memberikan komentar maka peneliti menganggap bahwa buku ajar berbasis scientific approach pada materi Gelombang Cahaya yang dikembangkan sudah baik dan sesuai dengan yang mereka inginkan. Dari uji coba yang dilakukan terhadap siswa dan guru dengan menggunakan angket didapatkan hasil data kepraktisan buku ajar Fisika berbasis berbasis scientific approach materi Gelombang Cahaya di kelas XI SMA Negeri 5 Lubuklinggau yaitu cukup praktis sehingga dapat digunakan untuk melakukan uji coba luas/besar. Hasil persentase respon siswa pada uji coba kelompok kecil disajikan dalam bentuk diagram berikut:

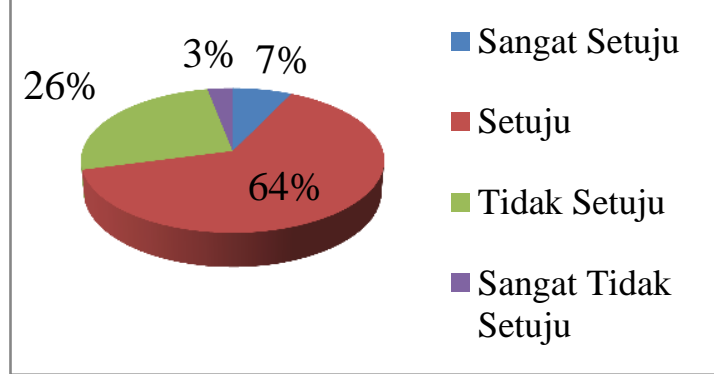

Gambar 4 Diagram hasil Respon siswa uji cobakelompok kecil

Tabel 2 Hasil Rekapitulasi Penilaian Angket Kepraktisan Kelompok Kecil

\begin{tabular}{ccccc}
\hline No. & Subjek & $\begin{array}{c}\text { Hasil } \\
\text { penilaian }\end{array}$ & Persentase & Ketegori \\
\hline 1 & Siswa & 184 & $76,66 \%$ & Setuju \\
\hline 2 & Guru & 34 & $85 \%$ & $\begin{array}{c}\text { Sangat } \\
\text { Setuju }\end{array}$ \\
\hline \multicolumn{2}{l}{ Total } & 218 & $80,83 \%$ & Setuju \\
\hline
\end{tabular}

Uji coba luas adalah uji coba pemakaian buku ajar yang dikembangkan. Dalam uji coba kelompok luas ini juga digunakan untuk melihat kepraktisan diberikan ke kelas XI IPA 2 SMA Negeri 5 Lubuklinggau dilaksanakan pada hari senin, 6 Agustus 2018 yang melibatkan 34 siswa yang terdiri dari 14 siswa lakilaki 20 siswa perempuan. Pelaksanaan pengerjaan angket respon kepraktisan dilakukan saat pembelajaran belum dimulai di dalam kelas pada jam 13.30 WIB pada pertemuan keempat.

Uji coba kepraktisan dilakukan kembali karena sesuai dengan model pengembangan yang digunakan mengenai buku ajar Fisika berbasis scientific approach materi Gelombang Cahaya. Angket yang diberikan sama dengan angket yang diberikan pada kelompok terbatas dan siswa dianjurkan untuk mengisi saran atau komentar di tempat yang telah disediakan. Dalam hal ini tidak ada lagi saran mengenai buku ajar namun terdapat beberapa komentar mengenai buku ajar yang dikembangkan. Selain siswa terdapat pula komentar kembali dari guru Fisika. Komentar yang diberikan berasal dari 27 siswa di kelas XI IPA 2 SMA Negeri 5 Lubuklinggau.

Komentar yang diberikan menunjukkan bahwa buku ajar yang dikembangkan telah sangau baik dan praktis untuk digunakan dalam pembelajaran. Melihat hal tersebut buku ajar berbasis scientific approach yang dikembangkan bisa diproduksi massal tanpa harus direvisi kembali. Dengan adanya komentar, peneliti mengetahui 
hal-hal yang dipikirkan siswa mengenai buku ajar yang diproduksi sehingga buku ajar bisa dikatakan praktis. Terbukti dengan banyaknya siswa yang merespon setuju untuk pernyataan yang dituliskan pada angket yang diberikan.

Selain siswa, ibu Siska, S.Pd juga kembali memberikan komentar terhadap buku ajar yang telah diperbaiki saat jam kosong di ruang guru. Saran dan masukkan untuk perbaikan buku ajar kedepannya sudah tidak ada lagi karena komentar yang diberikan merupakan tanggapan persetujuan atas semua indikator yang telah ada di dalam buku ajar. Dari hasil perhitungan angket kelompok luas didapatkan data sebagai berikut:

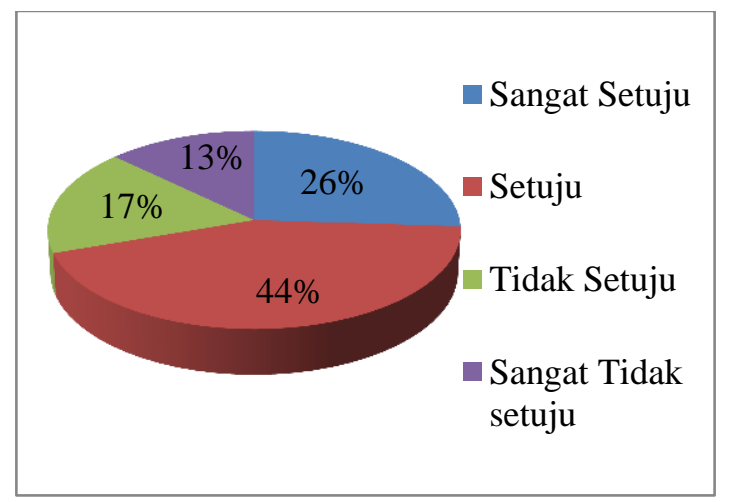

Gambar 5 Diagram hasil Respon siswa uji coba kelompok Luas

Tabel 3 Hasil Rekapitulasi Penilaian Angket Kepraktisan Kelompok Luas

\begin{tabular}{ccccc}
\hline \multicolumn{5}{c}{ Kepraktisan Kelompok Luas } \\
\hline 1 & Subjek & $\begin{array}{c}\text { Hasil } \\
\text { penilaian }\end{array}$ & Persentase & Ketegori \\
\hline 2 & 1143 & $84 \%$ & $\begin{array}{c}\text { Sangat } \\
\text { Baik }\end{array}$ \\
\hline \multicolumn{2}{c}{ Total } & 1178 & $85,77 \%$ & $\begin{array}{c}\text { Sangat } \\
\text { Baik }\end{array}$ \\
\hline
\end{tabular}

Dikarenakan angket yang diberikan terjadi 2 kali maka perlu diketahui nilai rata-rata untuk melihat persentase kepraktisan terhadap buku ajar Fisika berbasis scientific approach materi Gelombang Cahya di kelas XI. Berikut hasil analisis data dari penjumlahan nilai angket kelompok terbatas dan angket kelompok luas:

Tabel 4 Hasil Rekapitulasi Penilaian Angket Kepraktisan

\begin{tabular}{ccccc}
\hline No. & Subjek & $\begin{array}{c}\text { Hasil } \\
\text { penilaian }\end{array}$ & Persentase & Ketegori \\
\hline 1 & \multirow{2}{n}{2} & 184 & $76,66 \%$ & Baik \\
\cline { 3 - 5 } & Siswa & 1143 & $84 \%$ & $\begin{array}{c}\text { Sangat } \\
\text { Baik }\end{array}$ \\
\hline 3 & Guru & 34 & $85 \%$ & $\begin{array}{c}\text { Sangat } \\
\text { Baik }\end{array}$ \\
\cline { 3 - 5 } & & 35 & $87,55 \%$ & $\begin{array}{c}\text { Sangat } \\
\text { Baik }\end{array}$ \\
\hline & Total & 1396 & $83,22 \%$ & $\begin{array}{c}\text { Sangat } \\
\text { Baik }\end{array}$ \\
\hline
\end{tabular}

\section{Keefektivan Buku Ajar}

Susanto (2013) menyatakan bahwa pembelajaran efektif merupakan tolok ukur pembelajaran guru dalam mengelola kelas. Proses pembelajaran dikatakan efektif apabila seluruh peserta didik dapat terlibat secara aktif, baik mental, fisik, maupun sosialnya. Nini,dkk (2015) mengungkapkan bahwa efektifitas secara umum menunjukan sampai seberapa jauh tercapainya suatu tujuan yang lebih dahulu ditentukan. Berdasarkan pendapat yang telah dikemukakan di atas maka dapat disimpulkan bahwa efektifitas pembelajaran adalah sebuah tolok ukur tentang keberhasilan suatu proses belajar mengajar dan juga untuk menunjukan sampai seberapa jauh tercapainya suatu tujuan pembelajaran selain itu pembelajaran dikatakan efektif jika peserta didik yang tuntas dalam belajar adalah $75 \%$ dari jumlah siswa.

Untuk mengetahui keefektifan dari buku ajar yang dikembangkan maka akan diketahui dari hasil belajar kognitif siswa. Berdasarkan uraian di atas peneliti telah mendapatkan hasil dari uji coba kelompok luas untuk melihat keefektifan dari buku ajar yang dikembangkan. Uji kelompok luas ini dilakukan di kelas XI IPA 2 SMA Negeri 5 Lubuklinggau dengan menggunakan 1 kelas sebagai subjek dalam penelitian ini. Keefektifan buku ajar dilihat dari hasil belajar kognitif 
siswa. Hasil belajar dengan menggunakan soal tes yang berjumlah 10 soal dengan kriteria C1-C6. Nur (2015) mengungkapkan bahwa hasil belajar adalah ukuran keberhasilan siswa berupa pengetahuan ilmu, kecakapan yang dicapai sebagai hasil dari suatu yang dipelajari dalam jangka waktu tertentu. Hasil belajar siswa yang sesuai dengan penelitian yang telah dilakukan di kelas XI IPA 2 SMA Negeri 5 Lubuklinggau dengan ketuntasan klasikal sebesar $82 \%$ yang mampu melebihi nilai minimal $75 \%$ dari jumlah keseluruhan siswa dalam satu kelas. Dengan demikian dapat disimpulkan Buku ajar yang dikembangkan telah memenuhi kriteria keefektifan ditinjau dari hasil belajar kognitif siswa.

Untuk mencapai ketuntasan tersebut terdapat pula nilai rata-rata siswa yang bisa dihitung menggunakan t-test satu sampel dimana dalam hal ini $t_{\text {hitung }}=6,53$ dan $t_{\text {tabel }}=1,692$ karena $t_{\text {hitung }} \geq t_{\text {tabel }}$ sehingga dapat dikatakan $\mathrm{H}_{\mathrm{a}}$ diterima dan $\mathrm{H}_{\mathrm{o}}$ ditolak. Dengan demikian rata-rata nilai hasil belajar kognitif siswa dapat dikatakan tuntas. Dari beberapa penjelasan mengenai instrumen yang digunakan untuk mengukur keefektifan dari buku ajar berbasis scientific approach yang dikembangkan maka buku ajar dapat dikatakan efektif hasil belajar siswa mencapai angka $>75 \%$ dari jumlah keseluruhan siswa di dalam kelas. Dari hasil data diperoleh bahwa buku ajar yang dikembangkan telah efektif digunakan dalam proses pembelajaran. Dengan peresentasi seperti dijelaskan pada gambar di bawah ini:

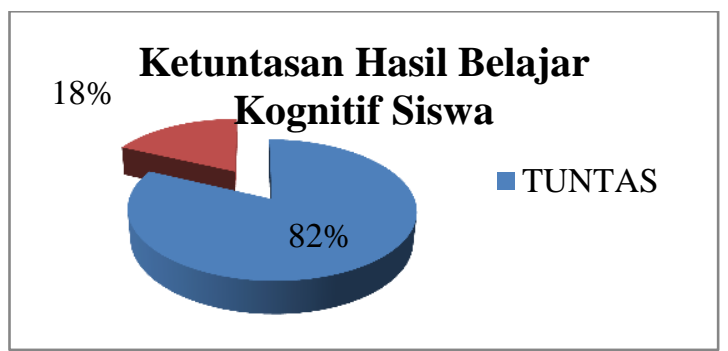

Gambar 6 Diagram hasil Kefektifan buku ajar dari segi Ketuntasan Hasil Belajar Kognitif Siswa

\section{SIMPULAN}

Peneliti melakukan proses pengembangan bahan ajar berbasis scientific approach pada materi gelombang cahaya. penelitian ini menggunakan model pengembangan milik Sugiyono melalui 10 tahapan mulai dari potensi dan masalah, pengumpulan data, desain produk, validasi desain, revisi desain, uji coba produk, revisi produk, uji coba pemakaian, revisi produk, dan produksi massal.

Hasil penilaian validator terhadap kualitas bahan ajar berbasis scientific approach pada komponen kelayakan materi memiliki persentase sebesar $75 \%$, sementara itu untuk komponen media memiliki persentase sebesar $83,3 \%$ dan untuk komponen kebahasaan memiliki persentase sebesar 79,1\%. Persentase keseluruhan komponen adalah 76,58\% sehingga bahan ajar berbasis scientific approach dikatakan valid dan memenuhi kriteria baik. Persentase keseluruhan komponen bahan ajar yang divalidasi oleh para ahli adalah 73,04\% sehingga bahan ajar berbasis scientific approach dikatakan valid dan memenuhi kriteria baik.

Persentase keseluruhan respon siswa terhadap bahan ajar berbasis scientific approach adalah $85,77 \%$ sehingga bahan ajar dikatakan praktis dan memenuhi kriteria setuju atau positif. Dan persentase hasil tes ulangan harian $82 \%$ siswa yang memperoleh nilai di atas 70 ada 28 siswa dan 6 siswa nilainya dibawah 70 dari sepuluh butir soal tes sehingga bahan ajar dikatakan efektif. Oleh karena itu, bahan ajar berbasis scientific approach materi Gelombang Cahaya tahun pelajaran 2018/2019 dapat dikatakan valid, praktis dan efektif 


\section{DAFTAR PUSTAKA}

Fatmawati, Agustina. (2016). Pengembangan Perangkat Pembelajaran Konsep Pencemaran Lingkungan Menggunakan Model Pembelajaran Berdasarkan Masalah Untuk Sma Kelas X. EduSains. 4 (2), 97.

Nini, Wa Ode, (2015).Efektivitas Penerapan Model Pembelajaran Kooperatif Tipe Think Pair Share Terhadap Hasil Belajar Matematika Materi Pokok Statistika Pada Siswa Kelas IX SMP Negeri 2 Kendari. Jurnal Penelitian Pendidikan Matematika 3(1), 153-166.

Nur, Anis. (2015). Penerapan Model Pembelajaran Generatif Untuk Meningkatkan Hasil Belajar Fisika Siswa Kelas XII IPA1 SMA Negeri 9 Makasar. Jurnal Pendidikan Fisika 3(1):1-13.

Prastowo, Andi. (2014). Pengembangan Bahan Ajar Tematik Tinjauan Teoretis Dan Praktis. Jakarta : Kencana.

Sukerni, Putu. (2014). Pengembangan Buku Ajar Pendidikan IPA Kelas IV Semester 1 SD No.4 Kaliuntu Dengan Model Dick And Carey. Jurnal Pendidikan Indonesia 3(1), 386-396.

Susanto, Ahmad. (2013). Teori Belajar Dan Pembelajaran di Sekolah Dasar. Jakarta: Prenadamedia Group.

Susilo, Agus, (2016). Pengembangan Modul Berbasis Pembelajaran Saintifik Untuk Peningkatan Kemampuan Mencipta Siswa Dalam Proses Pembelajaran Akuntansi Siswa Kelas XII SMA N 1 Slogohimo 2014. Jurnal Ilmu Pendidikan Sosial 26(1), 50-56.

Yerimadesi, (2016). Pengembangan Modul Kesetimbangan Kimia Berbasis Pendekatan Saintifik Untuk Kelas XI SMA/MA. Journal of Sainstek 8(1), 85-97. 